\title{
PIEZO2 wt Allele
}

National Cancer Institute

\section{Source}

National Cancer Institute. PIEZO2 wt Allele. NCI Thesaurus. Code C106087.

Human PIEZO2 wild-type allele is located in the vicinity of 18p11.21 and is approximately $479 \mathrm{~kb}$ in length. This allele, which encodes piezo-type mechanosensitive ion channel component 2 protein, plays a role in the conduction of mechanical impulses. 